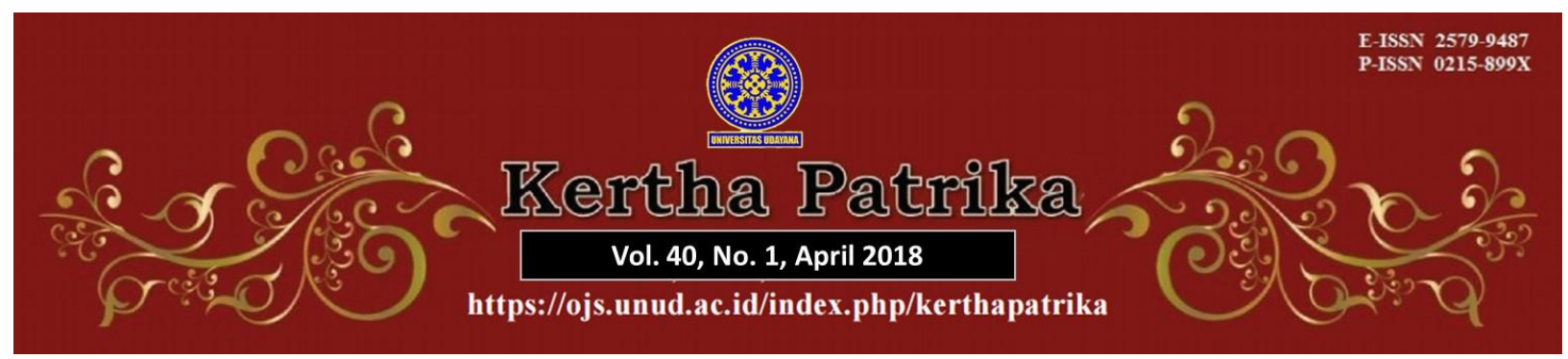

\title{
PENGATURAN KOMODITAS LADA DI PROVINSI KEPULAUAN BANGKA BELITUNG PERSPEKTIF ASAS-ASAS PEMBENTUKAN PERATURAN PERUNDANG-UNDANGAN
}

Oleh:

Darwance $^{1}$, Sigit Nugroho ${ }^{2}$, Yokotani ${ }^{3}$ Fakultas Hukum Universitas Bangka Belitung

\begin{tabular}{l}
\hline Info Artikel \\
\hline Keywords : \\
Pepper arrangement, \\
Legal Principles, \\
Legal Construction, \\
Regulations. \\
\\
\\
Kata kunci: \\
Pengaturan Lada, \\
Asas Hukum, \\
Pembentukan Peraturan \\
Perundang-Undangan. \\
\\
Corresponding Author: \\
Darwance \\
E-mail: \\
darwance@yahoo.co.id \\
DOI: \\
10.24843/KP.2018.v40.i01.p01 \\
\hline
\end{tabular}

\begin{abstract}
Bangka Belitung Islands Province is known as a producer of pepper and tin that became the region's flagship commodity. In order to manage the mining sector of tin and white pepper that has already got the protection of Geographical Indication, therefore to realize strong efforts of policymakers in the form of good legislation are needed for better community's welfare in that province. This is a normative legal research which is based on applicable laws and legal principles. The study shows that some aspects have indicated the fulfilment of the legal principles in the construction of regulation while there are still some legal principles that have not been fully used as a reference by local legislators.
\end{abstract}

\begin{tabular}{l} 
Abstrak \\
\hline Provinsi Kepulauan Bangka Belitung dikenal sebagai \\
penghasil lada dan timah yang menjadi komoditi \\
unggulan daerah tersebut. Dalam rangka pengelolaan \\
sektor pertambangan timah dan lada putih yang sudah \\
mendapat perlindungan Indikasi Geografis, maka \\
diperlukan upaya dari pengambil kebijakan dalam bentuk \\
pengaturan perundang-undangan yang baik guna \\
mewujudkan kesejahteraan masyarakat di provinsi \\
tersebut. Penelitian ini bersifat yuridis normatif, \\
pembahasan didasarkan pada perundang-undangan dan \\
prinsip hukum yang berlaku. Hasil studi menunjukkan \\
bahwa sejumlah aspek telah memenuhi asas-asas hukum \\
dalam pembentukan peraturan perundang-undangan, \\
kendatipun masih terdapat beberapa hal pula yang belum \\
sepenuhnya dijadikan sebagai acuan oleh pembentuk \\
peraturan daerah.
\end{tabular}

\footnotetext{
${ }^{1}$ Darwance adalah dosen pada Fakultas Hukum Universitas Bangka Belitung. Korespondensi dengan penulis melalui email : darwance@yahoo.co.id

${ }^{2}$ Sigit Nugroho adalah dosen pada Fakultas Hukum Universitas Bangka Belitung.

${ }^{3}$ Yakotani adalah dosen pada Fakultas Hukum Universitas Bangka Belitung.
} 


\section{Pendahuluan}

Indonesia sebagai negara maritim yang kaya akan hasil lautnya, juga sangat terkenal sebagai negara kepulauan yang kaya akan sumber alamnya. Salah satunya, Provinsi Kepulauan Bangka Belitung terkenal selain sebagai daerah penghasil timah juga daerah penghasil lada. Kekayaan alam tersebutlah yang menjadi salah satu faktor penyebab datangnya para penjajah untuk menduduki beberapa daerah di Indonesia pada masa silam. Salah satu daerah yang memiliki kekayaan alam terbanyak di Indonesia adalah Provinsi Kepulauan Bangka Belitung yang memiliki kekayaan rempah-rempah yang sangat terkenal berupa lada. Indonesia merupakan salah satu negara penghasil lada terbesar kedua di dunia setelah Vietnam. ${ }^{4}$

Lada yang oleh masyarakat di Kepulauan Bangka Belitung dikenal dengan sebutan "sahang" menjadi komoditi unggulan daerah tersebut. Masyarakat pun kemudian berinisiatif untuk menanam lada di tanah kosong yang mereka miliki. Sekalipun cenderung naik-turun, luas perkebunan lada sebetulnya terus bertambah dari waktu ke waktu. Demikian pula dengan harga lada yang cenderung terus naik dari tahun ke tahun. Berdasarkan data Direktorat Jenderal Perkebunan Kementerian Pertanian Republik Indonesia (2010), sampai saat ini Kepulauan Bangka Belitung merupakan provinsi yang memilik areal lada terluas kedua di Indonesia setelah Provinsi Lampung dan menjadi produksi lada putih (white pepper) paling besar di Indonesia. Sampai akhir tahun 90 -an pasokan lada putih dari Provinsi Kepulauan Bangka Belitung mencapai $60 \%-80 \%$ di pasar lada dunia. ${ }^{5}$

Dalam perkembangannya, luas lahan perkebunan lada terus berkurang, dikarenakan lahan yang dulunya digunakan untuk lahan perkebunan lada, beralih fungsi dan berubah menjadi tambang timah inkonvensional (TI). Berdasarkan data dari Dinas Pertambangan Perkebunan dan Peternakan Provinsi Kepulauan Bangka Belitung (Babel), Kabupaten Bangka Selatan memiliki luas areal perkebunan lada terbesar di Babel, yakni 23 hektar, 7 hektar di Bangka, 7 hektar di Belitung, 5 hektar di Bangka Barat, 3 hektar di Belitung Timur, dan 2 hektar di Bangka Tengah. ${ }^{6}$ Beralihnya masyarakat dari menanam lada ke penambangan timah, mengubah pula kehidupan masyarakat Provinsi Kepulauan Bangka Belitung. Sekarang, masyarakat di Provinsi Kepulauan Bangka Belitung mulai beralih kembali dari sektor tambang ke sektor pertanian dan perkebunan. Selain harganya yang relatif stabil dan tidak menyebabkan kerusakan alam, persediaan timah yang mulai berkurang diikuti dengan harga yang tidak stabil bahkan cenderung terus menurun juga menjadi salah satu faktor beralihnya mata pencaharian masyarakat dari tambang ke pertanian dan perkebunan.

Dengan kondisi seperti ini, berbagai upaya harus dilakukan oleh policy maker untuk mengelola sektor pertambangan khususnya timah dan sektor pertanian dan perkebunan khususnya lada guna mewujudkan kesejahteraan masyarakat di Provinsi

${ }^{4}$ Bank Indonesia. (2016). Kajian Model Pembiayaan Komunitas Lada di Provinsi Kepulauan Bangka Belitung. Kantor Perwakilan Bank Indonesia Perwakilan Provinsi Kepulauan Bangka Belitung Bekerjasama dengan Lembaga Penelitian dan Pengabdian Masyarakat Universitas Bangka Belitung. Pangkalpinang, h. 1.

${ }^{5}$ Ibid., h. 1.

${ }^{6}$ Lihat di http://bangka.tribunnews.com/2016/08/04/kebun-lada-terluas-ada-di-bangka-selatan, diakses pada tanggal 21 Juni 2017, pukul 13.30 WIB. 
Kepulauan Bangka Belitung. Sejumlah kebijakan di bidang hukum pun mutlak diperlukan untuk mendukung tata kelola timah dan hasil pertanian dan perkebunan guna mendukung kesejahteraan masyarakat di Provinsi Kepulauan Bangka Belitung, beranjak dari pengaturan perspektif historis. Dengan demikian, perlu dilakukan pengkajian soal kebijakan pengaturan lada dan timah yang pernah berlaku di Provinsi Kepulauan Bangka Belitung.

Penelitian yang berkaitan dengan perkembangan lada, khususnya kondisi kritis terjadinya penurunan lada putih di Bangka Belitung pernah dilakukan oleh Usman Daras dan D. Pranowo, hasil studinya menunjukkan bahwa alternatif yang dapat dilakukan untuk mengembalikan peran lada putih Bangka Belitung sebagai salah satu sentra produksi lada Indonesia melalui usaha: pewilayahan komoditas, diversifikasi usaha tani, penataan tata niaga lada, serta penguatan modal dan kelembagaan. ${ }^{7}$ Lebih lanjut, AA GD Santosa dan IB Erwin Ranawijaya dalam studinya pada tahun 2011 mengemukakan secara historis model pengaturan yang berkaitan dengan pengaturan komoditas fundamental ekonomi di Indonesia terklasifikasikan pada beberapa periode yakni: pengaturan pada masa berlaku tanam paksa oleh VOC, pengaturan modal asing di masa orde baru, pengaturan modal asing di masa revormasi, hingga pengaturan dengan prinsip non diskriminasi pada era General Agreement Trade and Services (GATs). ${ }^{8}$ Pengaturan komoditas lada maupun sumber daya alam lainnya di Indonesia tampaknya tidak dapat dilepaskan dari aspek permodalan, khususnya penguatan modal yang juga sangat ditentukan oleh aspek historis periode waktu dari dilakukannya suatu penguatan komoditas.

Tulisan ini bertujuan untuk mengkaji dan menganalisis secara lebih mendalam sejarah pengaturan lada yang pernah berlaku di Provinsi Kepulauan Bangka Belitung, untuk menemukan model pengaturan yang sesuai serta berbasis asas-asas pembentukan perundang-undangan sebagai suatu alternatif penguatan komoditas lada di Bangka Belitung.

\section{Metode Penelitian}

Penelitian ini bersifat yuridis normatif, pembahasan didasarkan pada perundangundangan dan prinsip hukum yang berlaku dilakukan dengan cara meneliti bahan pustaka $^{9}$ atau data sekunder belaka ${ }^{10}$. Penelitian ini menginventarisasi perundangundangan (kebijakan) yang berlaku, berupaya mencari asas-asas atau dasar falsafah dari perundang-undangan (kebijakan) tersebut, atau penelitian ini berusaha menemukan hukum yang sesuai dengan suatu kasus tertentu11, yakni mengenai

7 Daras, U., \& Pranowo, D. (2017). Kondisi kritis lada putih Bangka Belitung dan alternatif pemulihannya. Jurnal Penelitian dan Pengembangan Pertanian, 28(1), h.4.

8 Santosa, A. G. D. H., Ranawijaya, I. B. E., Ariana, I. G. P., Salain, N. M. S. P. D., \& Widiatedja, I. P. (2011). Prinsip Non Diskriminasi Perjanjian General Agreement On Trade In Services (GATS) Pada Pengaturan Penanaman Modal Asing Di Bidang Pariwisata Di Indonesia. KERTHA PATRIKA. 36(2), h. 73-76.

9 Soekanto, S. \& Mamuji, S. (2015). Penelitian Hukum Normatif Suatu Tinjauan Singkat. Rajawali Press. Jakarta, h. 13.

10 Salim, H. S. \& Nurbani, E. S. (2013). Penerapan Teori Hukum pada Penelitian Tesis dan Disertasi. Raja Grafindo Persada. Jakarta, h. 12.

${ }^{11}$ Nasution, B. J. (2008) Metode Penelitian Ilmu Hukum. Mandar Maju. Bandung, h. 86. 
permasalahan timah dan lada yang ada di Provinsi Kepulauan Bangka Belitung. Maksudnya untuk menemukan suatu aturan hukum, prinsip-prinsip hukum, maupun doktrin-doktrin hukum untuk menjawab permasalahan hukum yang dihadapi. ${ }^{12}$

Penelitian ini menggunakan pendekatan undang-undang (statute approach) dan pendekatan sejarah (historical approach). Pendekatan undang-undang dilakukan dengan menelaah semua undang-undang dan regulasi yang bersangkut paut dengan isu hukum yang sedang ditangani.13 Sedangkan pendekatan historis dilakukan dengan menelaah latar belakang apa yang dipelajari dan perkembangan pengaturan mengenai isu hukumm yang dihadapi. ${ }^{14}$ Bahan hukum yang digunakan dalam penelitian ini adalah bahan hukum primer, sekunder dan tersier yang bersumber dari penelitian kepustakaan. Bahan hukum primer yang digunakan dalam penelitian ini adalah dari berbagai peraturan perundang-undangan yang terkait. Bahan hukum sekunder dalam penelitian ini yang merupakan bahan hukum yang memberikan penjelasan mengenai bahan hukum primer yang berkaitan dengan penelitian ini, yaitu berupa rancangan perundang-undangan, kepustakaan, dokumen hukum yang terkait kebijakan lada, serta hasil penelitian sebelumnya yang terkait dengan permasalahan. Sedangkan bahan hukum tersier yang digunakan dalam penelitian ini adalah berbagai literatur yang memberikan penjelasan untuk bahan hukum primer dan bahan hukum sekunder. Teknik pengumpulan bahan hukum dalam penelitian ini dilakukan dengan studi pustaka. Dalam tulisan ini bahan-bahan hukum yang relevan dianalisis dengan menggunakan analisis deskriftif kualitatif.

\section{Hasil dan Pembahasan}

\subsection{Pengaturan Komoditas Lada Dalam Produk Legislasi}

Lada (Piper ningrum L.) merupakan salah satu komoditas unggulan Indonesia yang sudah dikenal di dunia. Sebagai salah satu komponen bumbu penyedap, lada dapat dipastikan dikonsumsi oleh seluruh manusia hampir setiap hari. Lada dengan demikian berada pada posisi yang sangat stategis terutama secara ekonomi. Oleh beberapa petani di beberapa daerah di Indonesia, lada pun menjadi salah satu tanaman yang dibudidayakan sekaligus menjadi sumber mata pencaharian utama. Sejumlah literasi dan studi terdahulu menyebutkan tanaman lada berasal dari India. ${ }^{15}$ Di negara ini, terdapat lebih dari 100 varietas lada. Saat ini, tanaman lada sudah menyebar ke bebagai negara, seperti Brazil, Malaysia, Sri Lanka, Myanmar, Indonesia, Kamboja, Vietnam, Thailand, dan Madagaskar. Di Asia Tenggara, penyebaran tanaman lada dimulai pada abad ke-16. Sekalipun lada menyebar di beberapa daerah di Indonesia, hanya ada beberapa daerah saja yang merupakan sentra produksi lada terbesar, di antaranya Kepulauan Bangka Belitung, Lampung, Bengkulu, Kalimantan Timur, Kalimantan Selatan, Kalimantan Barat, dan Sulawesi Selatan. Salah satu komuditas andalan ekspor tradisional bagi Indonesia adalah lada, bahkan pada tahun 2004 Indonesia menduduki peringkat kedua setelah Vietnam dalam produksi lada. ${ }^{16}$

12 Ibid.

${ }^{13}$ Marzuki, P. M. (2011). Penelitian Hukum. Kencana Prenada Media Group. Jakarta, h. 93-94.

${ }^{14}$ Ibid., h. 94-95.

${ }^{15}$ Jayasamudra, D.J. \& Cahyono, B. (2006). Lada Teknik Budi Daya dan Pascapanen. Aneka Ilmu, Semarang, h. 6.

16 Yuhono, J. T. (2007). Sistem Agribisnis Lada Dan Strategi Pengembangannya. Jurnal Litbang Pertanian, 26(2), h. 76. 
Tanaman lada masuk ke Indonesia sekitar abad ke-16 dibawa oleh koloni Hindu yang membuat lokasi perkebunan lada di daerah Cirebon, sebelum akhirnya menyebar ke berbagai daerah lain seperti Sumatera, Kalimantan, Sulawesi, termasuk Kepuluauan Bangka Belitung. ${ }^{17}$ Di Indonesia, ada dua daerah penghasil lada terpenting, yakni Pulau Bangka sebagai produsen lada putih dan Lampung sebagai produsen lada hitam.

Lada putih yang tumbuh di kepulauan Bangka Belitung karena memiliki ciri khas geografis Bangka Belitung dalam perspektif hukum kekayaan intelektual telah memenuhi persyaratan mendapatkan perlindungan Indikasi Geografis, oleh karenanya jenis tumbuhan ini sudah terdaftar dengan perlindungan Indikasi Geografis Direktorat Jendral Hak Kekayaan Intelektual Kementerian Hukum dan HAM dengan nama Lada Putih Muntok (Muntok White Pepper) oleh Badan Pengelola, Pengembangan dan Pemasaran Lada (BP3L) Provinsi Kepulauan Bangka Belitung pada tanggal 28 April 2010 dengan nomor pendaftaran ID G 000000004 dan nomor agenda G.00.2009.000002. Lada adalah komoditas dari Kepulauan Bangka Belitungkini resmi mendapat perlindungan indikasi geografis. ${ }^{18}$ Lada Putih Muntok dari Bangka Belitung beserta berbagai produk daerah lainnya seperti Tembakau Hitam dan Tembakau Mole dari Sumedang Jawa Barat maupun Ubi Cilembu juga dari Sumedang Jawa Barat telah terdaftar sebagai Indikasi Geografis. ${ }^{19}$ Perlindungan indikasi geografis memberi perlindungan tidak hanya manfaat ekonomi yang maksimal bagi masyarakat yang menghasilkan produk yang memiliki kekhasan sesuai geografis dimana produk khas tersebut bertumbuh dan dikembangkan, juga sekaligus memberi manfaat bagi konsumen karena kualitas produk yang terjamin. ${ }^{20}$ Berkaitan dengan perlindungan hukum bagi pemegang hak Indikasi geografis, pihaknya dapat mengajukan gugatan ganti rugi dalam hal produknya digunakan tanpa hak oleh pihak yang tidak berhak, juga pemusnahan etikat indikasi geografis oleh pihak yang tidak berhak. ${ }^{21}$

Lada di Provinsi Kepulauan Bangka Belitung menjadi tanaman yang ditanam petani sejak lama dan turun temurun hingga saat ini. Luas perkebunan lada di sini pun mengalami perubahan dari waktu ke waktu, bahkan sempat turun pada periode tertentu. Penurunan luas areal lada di Kepuluaan Bangka Belitung disebabkan oleh berbagai faktor. Empat faktor dominan yang menjadi penyebabnya adalah fluktuasi harga lada, gangguan OPT, dampak penambangan timah ilegal, dan pengembangan komoditas lain. ${ }^{22}$ Hanya saja, hingga kini, lada tetap menjadi komoditas yang masih ditanam oleh sebagian besar petani yang ada di Provinsi Kepulauan Bangka Belitung.

17 Sarpian. (2003). Pedoman Berkebun Lada dan Analisis Usaha Tani. Kanisius. Yogyakarta, h. 16.

18 Darwance. (2015). Lada Indikasi Geografis atau Paten? Bangka Pos. Bangka.

19 Djaja, H. (2013). Perlindungan Indikasi Geografis pada Produk Lokal dalam Sistem

Perdagangan Internasional. Jurnal Cakrawala Hukum, 18(2), h. 140.

${ }^{20}$ Yessiningrum, W. R. (2015). Perlindungan Hukum Indikasi Geografis sebagai Bagian dari Hak Kekayaan Intelektual. Jurnal IUS Kajian Hukum dan Keadilan, 3(1), h. 43.

${ }^{21}$ Ramli, T. A., \& Sumiyati, Y. (2009). Model Integrasi Lembaga Perwakilan untuk Pendaftaran sebagai Alternatif Pendaftaran untuk Memperoleh Perlindungan Hukum Indikasi Geografis Ubi Cilembu. Jurnal Hukum E Pembangunan, 39(1), h. 38.

22 Daras, U. \& Pranowo, D. (2009). Kondisi Kritis Lada Putih Bangka Belitung dan Alternatif Pemulihannya. Jurnal Litbang Pertanian, 28(1). 
Pada perkembangannya, lada memang menjadi isu sentral di Provinsi Kepulauan Bangka Belitung, utamanya setelah timah pelan-pelan mulai ditinggalkan dikarenakan cadangannya yang mulai menipis, terutama di darat. Sejumlah kebijakan pun diambil oleh pemerintah daerah, seperti promosi, pembentukan badan-badan tertentu, termasuk upaya pengendalian harga melalui beberapa produk legislasi. Salah satu produk legislasi yang dikeluarkan misalnya Peraturan Daerah Provinsi Kepulauan Bangka Belitung Nomor 2 Tahun 2004 tentang Pemasaran Lada Putih Bangka Belitung. Pada bagian konsideran menimbang disebutkan bahwa dikeluakannya peraturan daerah ini yakni dalam rangka meningkatkan pendapatan masyarakat petani lada putih maka perlu adanya kerjasama antara pemerintah kabupaten / kota dengan Pemerintah Provinsi Kepulauan Bangka Belitung dalam bidang pemasaran lada putih. Itu artinya, peraturan daerah ini lebih mengatur kerjasama antar daerah di lingkungan Provinsi Kepulauan Bangka Belitung dalam rangka meningkatkan pendapatan masyarakat yang berprofesi sebagai petani lada.

\subsection{Pengaturan Lada Berdasarkan Asas Pembentukan Peraturan Perundang- Undangan}

Pembentukan peraturan perundang-undangan, termasuk peraturan daerah umpanya, merupakan sebuah hal yang tidak bisa dihindari di negara hukum seperti Indonesia. Hal ini didasari atas beberapa hal, terutama sistem hukum yang seringkali diklasifikasikan sebagai negara dengan sistem hukum Eropa Kontinental (civil law), sekalipun tidak disebutkan secara tegas dalam sumber hukum mana pun, termasuk dalam UUD NRI 1945, Indonesia. Sistem hukum ini merupakan tradisi hukum yang tertua dan paling banyak berpengaruh dan meluas dipergunakan di dunia, mengandalkan kitab undang-undang (code) sebagai dasar hukum utama. ${ }^{23}$ Salah satu ciri paling penting adalah menjadikan undang-undang sebagai salah satu sumber hukum paling utama.

Dalam prosesnya, pembentukan peraturan perundang-undang tidak hanya melibatkan dua pihak, yakni pemerintah (eksekutif) dan legislatif, tetapi juga menuntuk kepiawaan penyusun undang-undang dalam menyusunnya. Menyusun sebuah peraturan perundang-undangan bukan hanya melarang atau memperbolehkan melakukan sesuatu beserta sanksi atas pelanggaran yang dilakukan, lebih dari itu adalah bagaimana norma yang diatur dilandasi atas asas-asas yang menjadi pijakan utama keberlakuan sebuah undang-undang. Asas hukum merupakan tiang utama bagi pembentukan peraturan perundang-undangan. Menurut IC Van den Vlies asas pembentukan peraturan negara yang baik meliputi asas formal dan asas materiil. Lebih lanjut menurut A hamid S. Attamimi, asas-asas materiil meliputi asas sesuai cita hukum Indonesia, norma fundamental negara, asas sesuai hukum dasar, asas sesuai dengan prinsip-prinsip negara berdasar atas hukum dan asas berdasar atas prinsipperinsip pemerintahan berdasarkan sistem konstitusi. ${ }^{24}$

Asas hukum (rechtsbeginsel) oleh Amiroeddin Sjarif diartikan sebagai dasar-dasar yang menjadi sumber pandangan hidup, kesadaran, cita-cita hukum dari masyarakat. ${ }^{25}$

23 Fuady, M. (2010). Perbandingan Ilmu Hukum. Refika Aditama. Bandung, h. 32.

24 Rosadi, O. (2010). Hukum Kodrat, Pancasila dan Asas Hukum dalam Pembentukan Hukum di Indonesia. Jurnal Dinamika Hukum. 10(3), h. 277-284. 
Bellefroid, asas hukum (umum) adalah norma dasar yang dijabarkan dari hukum positif dan yang oleh ilmu hukum tidak dianggap berasal dari aturan-aturan yang lebih umum. Sedangkan van Eikema Hommes mengatakan asas hukum itu tidak boleh dianggap sebagai norma-norma hukum yang konkret, akan tetapi perlu dipandang sebagai dasar-dasar umum atau petunjuk-petunjuk bagi hukum yang berlaku. Sebagaimana dikemukakan sebelumnya I.C. van der Vlies membagi asas-asas dalam pembentukan peraturan negara yang baik (geginselen van behoorlijke regelgeving) menjadi asas yang formal dan material. Formal meliputi asas tujuan yang jelas, asas organ/ lembaga yang tepat, asas perlunya pengaturan, asas dapatnya dilaksanakan, dan asas konsensus. Material meliputi asas tentang terminologi dan sistematika yang benar, asas tentang dapat dikenali, asas perlakuan yang sama dalam hukum, asas kepastian hukum dan asas pelaksanaan hukum sesuai keadaan individual. ${ }^{26}$

Dalam pembentukan peraturan perundang-undangan, A. Hamid S. Attamini mengemukakan bahwa selain berpedoman pada asas-asas pembentukan yang baik (beginselen van behoorlijke wetgeving), perlu juga dilandasi oleh asas-asas hukum umum (algemene rechtsbeginselen), terdiri dari asas negara berdasarkan hukum (rechtstaat), pemerintahan berdasarkan konstitusi, dan negara berdasarkan kedaulatan rakyat. ${ }^{27}$ Selanjutnya Bagir Manan berpandangan bahwa pembentukan perundang-undangan salah satunya harus mengacu pada landasan yuridis, seperti adanya kesesuaian bentuk produk-produk hukum dengan materi yang diatur, serta tidak boleh bertentangan dengan peraturan perundang-undangan yang lebih tinggi tingkatannya. ${ }^{28}$ Lebih lanjut, Erman Rajaguguk mengemukakan bahwa perundang-undangan yang baik harus sinkron satu dengan yang lainnya. ${ }^{29}$

Menurut Philipus M. Hudjon, asas perundang-undangan yang baik berfungsi sebagai dasar pengujian dalam pembentukan aturan hukum, maupun sebagai dasar pengujian terhadap aturan hukum yang berlaku. ${ }^{30}$ Satjipto Raharjo mengatakan bahwa asas hukum merupakan jantungnya peraturan hukum. ${ }^{31}$ Sehubungan dengan hal tersebut setiap pembentukan hukum haruslah berlandaskan pada asas-asas hukum.

Peraturan perundang-undangan yang baik, selain mengandung kepastian hukum, konsistensi dan kepercayaan, juga ketentuan tersebut dapat berkelanjutan. Untuk menghasilkan undang-undang dengan karakteristik berkelanjutan, unsur- unsur yang penting diperhatikan yaitu: keberhasilan dalam mencapai tujuan (doeltreffendheid), pelaksanaan (uitvoerbaarheid), dan penegakan hukumnya (handhaafbaarheid). Dalam konteks ini, menjadi penting melaksanakan tahapan perencanaan yang meliputi penyusunan naskah akademik, partisipasi publik, dan kesesuaian materi muatan dengan persyaratan pembentukan peraturan perundang-undangan. ${ }^{32}$ Asas penting lainnya dalam pembentukan peraturan perundang-undangan yang baik adalah

26 Indrati, M. F. S., (2007). Ilmu Perundang-Undangan: Proses dan Teknik Pembentukannya

(Buku 2). Kanisius. Yogyakarta, h. 254.

27 Yuliandri. (2009). Asas-Asas Pembentukan Peraturan Perundang-Undangan Yang Baik: Gagasan

Pembentukan Undang-Undang Berkelanjutan. Raja Grafindo. Jakarta, h. 115.

${ }^{28}$ Ibid., h. 134.

${ }^{29}$ Ibid., h. 136.

${ }^{30}$ Ibid., h. 166.

31 Raharjo, S. (2014). Ilmu Hukum, Citra Aditya Bakti. Bandung, h. 45.

32 Ibid. 
ditentukan dari sudut pandang pembuatnya. Suatu perundang-undangan harus dibentuk oleh lembaga yang tepat (het beginsel van het uiste organ). ${ }^{33}$ Asas-asas penting lainnya dalam perundang-undangan di antaranya: undang-undang tidak berlaku surut, lex specialis derogate lex generali, lex posteriori derogate lex priori, serta asas tidak dapat diganggu gugat. 34 Peraturan perundang-undangan memiliki ciri-ciri yaitu: bersifat umum, bersifat universal, dan memiliki kekatan untuk mengoreksi dan memperbaiki dirinya sendiri. ${ }^{35}$ Keberadaan peraturan yang memiliki ciri bersifat umum tidak hanya terbatas pada undang-undang, tetapi juga keputusan administrasi negara yang bersifat mengatur, seperti PP, Perpres, Permen, Peraturan Gubernur (Pergub), Peraturan Bupati (Perbub)/ Walikota. ${ }^{36}$

Penelitian yang dilakukan ini hanya menitiberatkan kepada asas-asas pembentukan peraturan perundang-undangan sebagaimana yang tercantum dalam Pasal 5 UndangUndang Nomor 12 Tahun 2011 tentang Pembentukan Peraturan PerundangUndangan. Asas-asas itu meliputi meliputi; (1) kejelasan tujuan; (2) kelembagaan atau pejabat pembentuk yang tepat; (3) kesesuaian antara jenis, hierarki, dan materi muatan; (4) dapat dilaksanakan; (5) kedayagunaan dan kehasilgunaan; (6) kejelasan rumusan; dan (7) keterbukaan.

Dari hasil penelitian yang sudah dilakukan, ditemukan beberapa peraturan perundang-undangan yang mengatur tentang lada dan timah di Bangka Belitung. Pengaturan tentang lada, di antaranya adalah Peraturan Daerah Provinsi Kepulauan Bangka Belitung Nomor 2 Tahun 2004 tentang Pemasaran Lada Putih Bangka Belitung. Perda ini ditetapkan pada tanggal 24 Februari 2004. ada beberapa hal yang diatur, yakni hak dan kewajiban eksportir, pemasaran, pelaksana pemasaran lada putih, pengawasan, sanksi dan penyidikan.

Lada yang dimaksud oleh perda ini adalah lada putih, buah lada yang telah mengalami proses setelah pasca panen melalui perendaman, pengupasan dan penjemuran yang menghasilkan lada putih berkualitas standar. Hak melakukan pengiriman lada putih ke luar negeri diberikan kepada eksportir, yakni Eksportir adalah Badan Usaha atau Perorangan yang melakukan kegiatan Ekspor. Eksportir berkewajiban memiliki Surat Izin Usaha Perdagangan (SIUP) atau izin usaha dari instansi teknis lainnya berdasarkan peraturan yang berlaku, mendaftarkan perusahaannya ke Kantor Pemasaran Bersama (KPB), memiliki gudang dan mesin atau peralatan sortasi yang memenuhi syarat dan mampu memproduksi lada putih kualitas ekspor, memiliki Tanda Daftar Perusahaan (TDP), memiliki Nomor Pokok Wajib Pajak (NPWP), menyampaikan laporan kegiatan usaha setiap 3 (tiga) bulan sekali kepada Gubernur. Kewajiban eksportir ini berpedoman kepada peraturan perundangundangan.

33 Ibid., h. 206.

${ }^{34}$ Dianut dalam Pasal 130 (2) Konstitusi RIS 1949 dan Pasal 95 (2) UUDS 1950. Ranggawidjaja., R. (1998). Pengantar Ilmu Perundang-Undangan Indonesia.Mandar Maju. Bandung, h. 51.

35 Astawa, I. G. P. (2012). Dinamika Hukum dan Ilmu Perundang-Undangan di Indonesia. Alumni. Bandung, h. 19. 
Pada bagian berikutnya, diatur tentang pelaksana pemasaran lada putih. Izin pengiriman lada putih ke luar wilayah pabean Republik Indonesia dapat diberikan kepada; (1) eksportir yang telah mendapat Kontrak penjualan dari Kantor Pemasaran Bersama; (2) eksportir tersebut harus mendapatkan Surat Persetujuan Ekspor Lada Putih (SPELP) yang diterbitkan oleh Dinas Perindustrian, Perdagangan, Koperasi dan UKM. Selain itu, tata cara pengiriman lada putih ke luar daerah dengan volume melebihi $50 \mathrm{~kg}$ (lima puluh kilogram) wajib dilengkapi dengan Surat Persetujuan Pengiriman Lada Putih Antar Daerah (SPPAD).

Pemasaran Lada Putih Bangka Belitung dilaksanakan oleh Kantor Pemasaran Bersama (KPB). Kantor Pemasaran Bersama (KPB) dan pelaksana operasional Kantor Pemasaran Bersama (KPB) dibentuk dengan Keputusan Gubernur yang dalam melaksanakan tugasnya Kantor Pemasaran Bersama (KPB) bertanggung jawab kepada Gubernur. Tugas Kantor Pemasaran Bersama (KPB) adalah:

a. memasarkan lada putih.

b. mengatur volume penjualan kepada para eksportir.

c. mendukung upaya peningkatan mutu lada putih ditingkat eksportir maupun petani.

d. melakukan penelitian bersama instansi terkait dalam rangka penganekaragaman produk lada putih.

Hak Kantor Pemasaran Bersama (KPB) adalah; (1) mengatur sistem pemasaran lada putih; (2) memperoleh komisi penjualan sebesar 2,5\% (dua koma lima persen) dari nilai kontrak penjualan yang digunakan untuk biaya operasional Kantor Pemasaran Bersama sebesar 0,75 \% (nol koma tujuh puluh lima persen), pembagian kepada Pemerintah Provinsi, Pemerintah Kabupaten dan Pemerintah Kota sebesar 0,5\% (nol koma lima persen), dan biaya pembinaan petani lada putih sebesar 1,25\% (satu koma dua puluh lima persen). Kantor Pemasaran Bersama (KPB) berkewajiban; (1) menjamin harga lada putih di pasar lokal tidak berada di bawah harga dasar; (2) menyampaikan harga dasar lada putih; (3) memberikan informasi setiap hari harga lada putih di tingkat internasional kepada para eksportir, pedagang antar pulau, pedagang pengumpul dan petani; (4) memberikan informasi kepada masyarakat harga lada hitam di tingkat lokal petani Lampung, Serawak, dan Vietnam; (5) melaporkan kegiatannya setiap akhir bulan kepada Gubernur.

Secara substansi, inilah beberapa hal yang diatur dalam Peraturan Daerah Nomor 2 Tahun 2004 tentang Pemasi dalam pembentukan peratu terpenuhi dan masih ada $b$ acuan oleh pembentuk perat

Dari aspek asas kejelasan tujuan, peraturan daerah ini sudah dibentuk dengan tujuan yang cukup jelas. Asas kejelasan tujuan adalah bahwa setiap Pembentukan Peraturan Perundang-undangan harus mempunyai tujuan yang jelas yang hendak dicapai. Hal ini bisa dilihat di bagian konsideran menimbang, yakni dalam rangka meningkatkan pendapatan masyarakat petani lada putih maka perlu adanya kerjasama antara Pemerintah Kabupaten / Kota dengan Pemerintah Provinsi Kepulauan Bangka Belitung dalam bidang Pemasaran Lada Putih. 
Dikaji dari asas kelembagaan atau pejabat pembentuk yang tepat, perda ini sudah dibentuk oleh lembaga yang berwenang sebagaimana amanat undang-undang, yakni DPRD atas persetujuan bersama dengan gubernur. Adapun yang dimaksud dengan asas kelembagaan atau pejabat pembentuk yang tepat adalah bahwa setiap jenis Peraturan Perundang-undangan harus dibuat oleh lembaga negara atau pejabat Pembentuk Peraturan Perundang-undangan yang berwenang. Peraturan Perundangundangan tersebut dapat dibatalkan atau batal demi hukum apabila dibuat oleh lembaga negara atau pejabat yang tidak berwenang.

Asas kesesuaian antara jenis, hierarki, dan materi muatan" adalah bahwa dalam Pembentukan Peraturan Perundang-undangan harus benarbenar memperhatikan materi muatan yang tepat sesuai dengan jenis dan hierarki Peraturan Perundangundangan. Pasal 14 UU P3 menegaskan bahwa materi muatan Peraturan Daerah Provinsi dan Peraturan Daerah Kabupaten/Kota berisi materi muatan dalam rangka penyelenggaraan otonomi daerah dan tugas pembantuan serta menampung kondisi khusus daerah dan/atau penjabaran lebih lanjut peraturan perundang-undangan yang lebih tinggi. Dilihat dari bagian konsideran mengingat, dapat disimpulkan bawah perda ini dibentuk salah satunya merupakan penjabaran lebih lanjut dari beberapa undang-undang, beberapa di antaranya yakni Undang-undang Nomor 10 Tahun 1995 tentang Kepabeanan (Lembaran Negara Tahun 1995 Nomor 75, Tambahan Lembaran Negara Nomor 3612) dan Undang-undang Nomor 5 Tahun 1999 tentang Larangan Praktek Monopoli dan Persaingan Usaha Tidak Sehat (Lembaran Negara Tahun 1999 Nomor 33, Tambahan Lembaran Negara Nomor 3817).

Asas dapat dilaksanakan adalah bahwa setiap Pembentukan Peraturan Perundangundangan harus memperhitungkan efektivitas Peraturan Perundang-undangan tersebut di dalam masyarakat, baik secara filosofis, sosiologis, maupun yuridis. Dari perspektif ini, sepertinya perda ini tidak terlal efektif diterapkan di masyarakat petani lada. Hal ini dibuktikan dengan tidak tercapainya tujuan yang hendak dicapai, yakni harga lada yang tetap tinggi. Padahal, apabila dikaji dari aspek asas kedayagunaan dan kehasilgunaan, perda ini dibuat karena karena memang benar-benar dibutuhkan dan bermanfaat dalam mengatur kehidupan bermasyarakat, berbangsa, dan bernegara. Dalam penyusunan peraturan perundang-undangan, asas kejelasan rumusan merupakan salah satu asas paling penting, yakni bahwa setiap peraturan perundangundangan harus memenuhi persyaratan teknis penyusunan peraturan perundangundangan, sistematika, pilihan kata atau istilah, serta bahasa hukum yang jelas dan mudah dimengerti sehingga tidak menimbulkan berbagai macam interpretasi dalam pelaksanaannya. Pada bagian ketentuan pidana, yakni Pasal 16, ada penggunaan bahasa hukum yang kurang jelas sehingga bisa memicu terjadinya multi interpretasi (penafsiran).

Pasal 16 Peraturan Daerah Nomor 2 Tahun 2004 tentang Pemasaran Lada Putih Bangka Belitung;

(1) Pelanggaran terhadap ketentuan Peraturan Daerah ini diancam dengan pidana kurungan paling lama 6 (enam) bulan atau denda sebanyak-banyaknya Rp. 5.000.000,00 (lima juta rupiah).

(2) Selain ketentuan pidana sebagaimana dimaksud pada ayat (1), terhadap pelaku tindak pidana dibidang pemasaran Lada Putih Bangka Belitung dapat dikenakan sanksi pidana 
lain sesuai dengan peraturan perundang-undangan. Ketentuan mana yang dimaksud, tidak tegas dinyatakan dalam pasal ini.

\section{Kesimpulan}

Berkaitan dengan keberadaan lada dan timah di Bangka Belitung ditemukan beberapa peraturan perundang-undangan yang mengatur di antaranya: Peraturan Daerah Provinsi Kepulauan Bangka Belitung Nomor 2 Tahun 2004 tentang Pemasaran Lada Putih Bangka Belitung, yang pada intinya mengatur hak dan kewajiban eksportir, pemasaran, pelaksana pemasaran lada putih, pengawasan, sanksi dan penyidikan. Berdasarkan kajian asas kelembagaan atau pejabat pembentuk yang tepat, perda ini sudah dibentuk oleh lembaga yang berwenang sebagaimana amanat undang-undang, yakni DPRD atas persetujuan bersama dengan gubernur. Adapun yang dimaksud dengan asas kelembagaan atau pejabat pembentuk yang tepat adalah bahwa setiap jenis Peraturan Perundang-undangan harus dibuat oleh lembaga negara atau pejabat Pembentuk Peraturan Perundang-undangan yang berwenang. Peraturan Perundangundangan tersebut dapat dibatalkan atau batal demi hukum apabila dibuat oleh lembaga negara atau pejabat yang tidak berwenang.

\section{Daftar Pustaka}

\section{Buku}

Astawa, I. G. P. (2012). Dinamika Hukum dan Ilmu Perundang-Undangan di Indonesia, Bandung. Alumni.

Bank Indonesia. (2016) Kajian Model Pembiayaan Komunitas Lada di Provinsi Kepulauan Bangka Belitung. Kantor Perwakilan Bank Indonesia Perwakilan Provinsi Kepulauan Bangka Belitung Bekerjasama Dengan Lembaga Penelitian dan Pengabdian Masyarakat Universitas Bangka Belitung. Pangkalpinang.

Fuady, M. (2010). Perbandingan Ilmu Hukum. Refika Aditama. Bandung.

Indrati, M. F. S., (2007). Ilmu Perundang-Undangan: Proses dan Teknik Pembentukannya (Buku 2). Kanisius. Yogyakarta.

Jayasamudra, D.J. \& Cahyono, B. (2006). Lada Teknik Budi Daya dan Pascapanen. Aneka Ilmu, Semarang.

Marzuki, P. M. (20110. Penelitian Hukum. Kencana Prenada. Media Group. Jakarta.

Nasution, B. J. (2008) Metode Penelitian Ilmu Hukum. Mandar Maju. Bandung.

Raharjo, S. (2014). Ilmu Hukum, Citra Aditya Bakti. Bandung.

Ranggawidjaja., R. (1998). Pengantar Ilmu Perundang-Undangan Indonesia.Mandar Maju. Bandung. 
Salim, H. S. \& Nurbani, E. S. (2013). Penerapan Teori Hukum Pada Penelitian Tesis dan Desertasi. Raja Grafindo Persada. Jakarta.

Sarpian. (2003). Pedoman Berkebun Lada dan Analisis Usaha Tani. Kanisius. Yogyakarta.

Soekanto, S. \& Mamuji, S. (2015). Penelitian Hukum Normatif Suatu Tinjauan Singkat. Rajawali Press. Jakarta.

Yuliandri. (2009). Asas-Asas Pembentukan Peraturan Perundang-Undangan Yang Baik: Gagasan Pembentukan Undang-Undang Berkelanjutan. Raja Grafindo. Jakarta.

\section{Jurnal}

Daras, U. \& Pranowo, D. (2017). Kondisi Kritis Lada Putih Bangka Belitung dan Alternatif Pemulihannya. Jurnal Penelitian dan Pengembangan Pertanian, 28(1), 16.

Djaja, H. (2013). Perlindungan Indikasi Geografis pada Produk Lokal dalam Sistem Perdagangan Internasional. Jurnal Cakrawala Hukum, 18(2).

Rosadi, O. (2010). Hukum Kodrat, Pancasila dan Asas Hukum dalam Pembentukan Hukum di Indonesia. Jurnal Dinamika Hukum, 10(3), 277-284

Ramli, T. A., \& Sumiyati, Y. (2009). Model Integrasi Lembaga Perwakilan untuk Pendaftaran sebagai Alternatif Pendaftaran untuk Memperoleh Perlindungan Hukum Indikasi Geografis Ubi Cilembu. Jurnal Hukum \& Pembangunan, 39(1), 14-57.

Santosa, A. G. D. H., Ranawijaya, I. B. E., Ariana, I. G. P., Salain, N. M. S. P. D., \& Widiatedja, I. P. (2011). Prinsip Non Diskriminasi Perjanjian General Agreement on Trade in Services (GATS) Pada Pengaturan Penanaman Modal Asing Di Bidang Pariwisata Di Indonesia. KERTHA PATRIKA. 36(2).

Yessiningrum, W. R. (2015). Perlindungan Hukum Indikasi Geografis sebagai Bagian dari Hak Kekayaan Intelektual. Jurnal IUS Kajian Hukum dan Keadilan, 3(1)

Yuhono, J. T. (2007). Sistem Agribisnis Lada dan Strategi Pengembangannya. Jurnal Litbang Pertanian, 26(2), 76

\section{Peraturan Perundang-Undangan}

Undang-Undang Nomor 12 Tahun 2012 Tentang Pembentukan Peraturan PerundangUndangan.

Peraturan Daerah Provinsi Kepulauan Bangka Belitung Nomor 2 Tahun 2004 Tentang Pemasaran Lada Putih Bangka Belitung

\section{Internet}

Lihat di http://bangka.tribunnews.com/2016/08/04/kebun-lada-terluas-ada-di-bangka-selatan, diakses pada tanggal 21 Juni 2017, pukul 13.30 WIB.

Darwance. (2015). Lada Indikasi Geografis atau Paten? Bangka Pos. Bangka. 